\title{
THE SKLAR APHASIA SCALE IN A FOREIGN LANGUAGE
}

\author{
Marion Fredman, M.A. (Rand) \\ Haifa, lsrael
}

Testing an adult aphasic patient is a complicated procedure liable to. depress and frustrate the patient if not handled correctly. Testing a bilingual or polyglot adult aphasic is fraught with added difficulties. Apart from the inconsistent responses which a patient may give due to severity of illness or confusion, the bilingual or polyglot patient may be faced with responding to questions in a language with which he was not completely familiar prior to illness. No test can replace extensive observation by a trained clinician. Bui a suitably designed test provides a starting point for observation and a guide to planning therapy.

In a study carried out recently in Haifa. Israel (Fredman ${ }^{2}$ ), the writer was faced with the problem of testing 20 adult aphasic patients in Hebrew which was not their primary language. Some patients had only had a scant knowledge of Hebrew prior to illness. One patient was illiterate and others had only been literate in their home language (Table I). Thus an aphasic test had to be selected which would lend itself to translation and adaptation into the Hebrew language, and yet would not provide long or difficult passages for reading.

The Sklar Aphasic Scale (SAS). was chosen because it aims at testing ". . . over learned functional communication skills" (Sklar ${ }^{7}$ ). This scale was developed by Dr. Maurice Sklar at Wadsworth Veterans Hospital in Los Angeles, California, and studies have been reported establishing the validity of the scale, Sklar ${ }^{6}$ and McCloud ${ }^{3}$.

The SAS attempts to assess overt residual language behaviour and is based on the communication theory which "... affirms that a social communication occurs when a sign is (1) decoded (received and comprehended), (2) transcoded (transformed internally), and (3) encoded (transmitted orally or graphically)" (Sklar ${ }^{7}$ ).

Thus, the SAS material is organized into four subtests:

(1) Auditory Decoding: This includes items measuring auditory verbal comprehension and the patient is only required to respond with a motor response or gesture.

(2) Visual Decoding: This subtest attempts to test the patient's "... ability to recognize and analyse different types of graphic signs usually acquired with formal learning" (Sklar?).

(3) Oral Encoding: Items previously presented for decoding are now presented for naming. The patient is also required to describe a picture and read a short news item. 


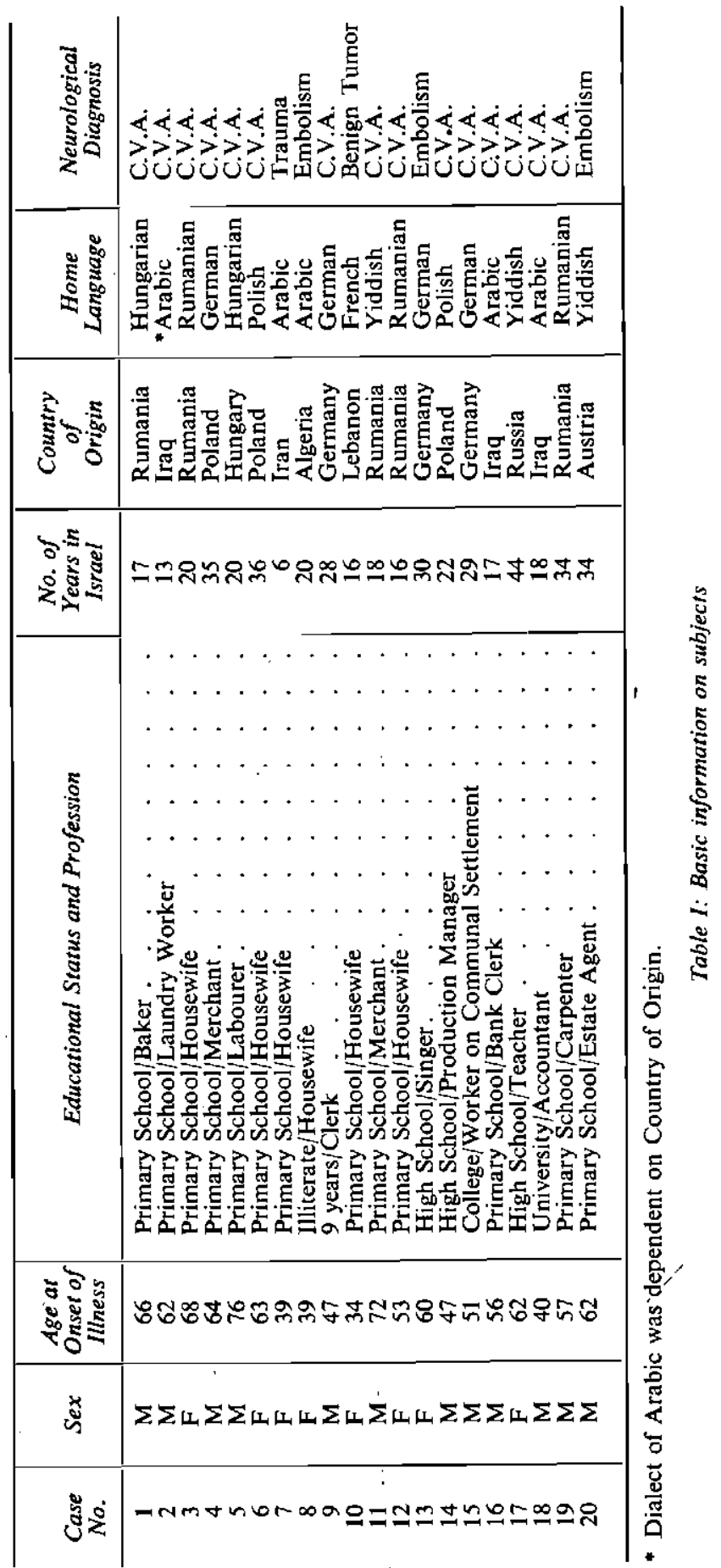

Journal of the South African Speech and Hearing Association, Vol. 18, December 1971 
(4) Graphic Encoding: This tests the patient's ability to write items presented in previous subtests, to write about the picture presented in subtests 2 and 3 , and to write progressively longer sentences dictated by the examiner.

Scoring is as follows: When a patient is able to respond without difficulty he is scored " $O$ " indicating no impairment; if he requires some assistance he is scored " 1 " and no response or an incorrect response is scored as "2". Sklar considers a score of " 1 " as a difficulty in transcoding ability. Each subtest has a possible impairment score of 100 and a prognosis of retraining potential is made on the basis of the total impairment score obtained by dividing the sum of all the scores by 4 .

\begin{tabular}{|c|c|c|c|c|c|c|c|c|}
\hline \multirow{3}{*}{ Case } & \multicolumn{2}{|c|}{ SAS* $^{*}$} & \multicolumn{2}{|c|}{ SAS } & \multicolumn{2}{|c|}{ L.M.T.A. } & \multicolumn{2}{|c|}{ H.L.Q. } \\
\hline & 1 & 2 & 3 & 4 & 5 & 6 & 7 & 8 \\
\hline & test & retest & test & retest & test & retest & test & retest \\
\hline $\begin{array}{r}1 \\
2 \\
3 \\
4 \\
5 \\
6 \\
7 \\
8 \\
9 \\
10 \\
11 \\
12 \\
13 \\
14 \\
15 \\
16 \\
17 \\
18 \\
19 \\
20\end{array}$ & $\begin{array}{r}372 \\
326 \\
360 \\
304 \\
294 \\
318 \\
316 \\
242 \\
158 \\
174 \\
208 \\
192 \\
124 \\
224 \\
44 \\
44 \\
58 \\
116 \\
- \\
-\end{array}$ & $\begin{array}{r}374 \\
204 \\
256 \\
296 \\
88 \\
178 \\
172 \\
148 \\
90 \\
142 \\
146 \\
172 \\
26 \\
42 \\
36 \\
24 \\
16 \\
119 \\
- \\
-\end{array}$ & $\begin{array}{r}372 \\
326 \\
360 \\
304 \\
294 \\
318 \\
316 \\
242 \\
158 \\
174 \\
208 \\
192 \\
124 \\
224 \\
44 \\
44 \\
58 \\
116 \\
362 \\
364\end{array}$ & $\begin{array}{r}374 \\
204 \\
256 \\
296 \\
88 \\
178 \\
172 \\
148 \\
90 \\
142 \\
146 \\
172 \\
26 \\
42 \\
36 \\
24 \\
16 \\
119 \\
318 \\
376\end{array}$ & $\begin{array}{r}412 \\
341 \\
420 \\
289 \\
305 \\
420 \\
298 \\
256 \\
173 \\
195 \\
365 \\
200 \\
147 \\
221 \\
78 \\
125 \\
88 \\
145 \\
- \\
-\end{array}$ & $\begin{array}{r}405 \\
242 \\
263 \\
261 \\
120 \\
229 \\
177 \\
160 \\
96 \\
155 \\
239 \\
158 \\
70 \\
79 \\
68 \\
67 \\
76 \\
86 \\
- \\
-\end{array}$ & $\begin{array}{l}80 \\
84 \\
53 \\
64 \\
68 \\
69 \\
79 \\
63 \\
33 \\
55 \\
55 \\
44 \\
48 \\
46 \\
31 \\
24 \\
21 \\
22 \\
79 \\
80\end{array}$ & $\begin{array}{l}85 \\
54 \\
27 \\
59 \\
24 \\
41 \\
44 \\
39 \\
21 \\
29 \\
42 \\
34 \\
21 \\
22 \\
26 \\
20 \\
20 \\
21 \\
74 \\
78\end{array}$ \\
\hline
\end{tabular}

* Note: Cases No. 1 and 2 as shown in Table $I$ are presented as No. 19 and 20 as they have no L.M.T.A. results. In calculating the $r_{s}$ between the SAS and H.L.Q. they again appear as No. 1 and 2.

Table II: Raw Scores

Because of the choice of test items in the SAS, and the fact that it tests functional language ability it was found to be an easy test both to translate and to administer. The SAS does not probe as deeply into the patient's linguistic problems as do tests such as the L.M.T.A. (Wepman-Jones $^{8}$ ) or M.T.D.D.A. $\left(\right.$ Schuell $^{4}$ ), but it is for this very reason that the writer found it suitable for patients whose knowledge of the test language had not been extensive prior to illness.

The passages provided to test reading comprehension are simple newspaper articles which the average Israeli patient is used to reading. The objects chosen for naming are known ones in Israel and were not 


\begin{tabular}{|c|c|c|c|c|c|c|c|c|}
\hline \multirow{3}{*}{ Case } & \multicolumn{2}{|c|}{ SAS } & \multicolumn{2}{|c|}{ SAS } & \multicolumn{2}{|c|}{ L.M.T.A. } & \multicolumn{2}{|c|}{ H.L.Q. } \\
\hline & 1 & 2 & 3 & 4 & 5 & 6 & 7 & 8 \\
\hline & test & retest & test & retest & test & retest & test & retest \\
\hline 1 & 1 & 1 & 3 & 3 & 3 & 1 & 4.5 & 3 \\
\hline 2 & 3 & 4 & 2 & 1 & 5 & 4 & 2.5 & 2 \\
\hline $\begin{array}{l}3 \\
4\end{array}$ & $\frac{2}{6}$ & $\begin{array}{l}3 \\
2\end{array}$ & $\begin{array}{l}1 \\
5\end{array}$ & $\begin{array}{l}2 \\
6\end{array}$ & $\begin{array}{l}1.5 \\
8\end{array}$ & $\frac{2}{3}$ & 2.5 & $\begin{array}{l}1 \\
5\end{array}$ \\
\hline 5 & 7 & 13 & 4 & 5 & 6 & 11 & 12 & 12 \\
\hline 6 & 4 & 5 & 8 & 4 & 1.5 & 6 & 8 & 4 \\
\hline 7 & 5 & 6.5 & 9 & 1.5 & 7 & 7 & 7 & 14 \\
\hline 8 & 8 & 8 & 6 & 7 & 9 & 8 & 6 & 8 \\
\hline 9 & 13 & 12 & 7 & 8.5 & 13 & 12 & 4.5 & 6 \\
\hline 10 & 12 & 10 & 10 & 10 & 12 & 10 & 9 & 9 \\
\hline 11 & 10. & 9 & 15. & 14 & 4 & 5 & 16 & 17 \\
\hline 12 & 11 & 6.5 & .14. & 12 & 11 & 9 & 10.5 & 11 \\
\hline 13 & 14 & 16 & 12 & 11 & 14 & 16 & 10.5 & 7 \\
\hline 14 & 9 & 14 & 13 & 8.5 & 10 & 14 & 15 & \\
\hline 15 & 17.5 & 15 & 16 & 18 & 18 & 17 & 13 & 17 \\
\hline 16 & 17.5 & 17 & 11 & 16 & 16 & 18 & 14 & 15 \\
\hline 17 & 16 & 18 & 19.5 & 17 & 17 & 15 & 17 & 13 \\
\hline 18 & 15 & 11 & 19.5 & 19 & 15 & 13 & 18 & 19.5 \\
\hline 19 & - & - & 18 & 20 & - & - & 20 & 19.5 \\
\hline 20 & - & - & 17 & 13 & - & - & 19 & 17 \\
\hline
\end{tabular}

Table III: Rank Scores

\begin{tabular}{|c|c|c|c|c|}
\hline \multirow{3}{*}{ Case } & \multicolumn{2}{|c|}{ Test } & \multicolumn{2}{|c|}{ Retest } \\
\hline & \multicolumn{2}{|c|}{ (1) and (5) of Raw Scores } & \multicolumn{2}{|c|}{ (2) and (6) of Raw Scores } \\
\hline & $d_{1}$ & $d_{i}^{2}$ & $\mathrm{~d}_{\mathrm{t}}$ & $\mathrm{d}_{2}$ \\
\hline $\begin{array}{r}1 \\
2 \\
3 \\
4 \\
5 \\
6 \\
7 \\
8 \\
9 \\
10 \\
11 \\
12 \\
13 \\
14 \\
15 \\
16 \\
17 \\
18\end{array}$ & $\begin{array}{c}-2 \\
-2 \\
0.5 \\
-2 \\
1 \\
2.5 \\
-2 \\
-1 \\
0 \\
0 \\
6 \\
0 \\
0 \\
-1 \\
-0.5 \\
1.5 \\
-1 \\
0\end{array}$ & $\begin{array}{l}4 \\
4 \\
0.25 \\
4 \\
1 \\
6.25 \\
4 \\
1 \\
0 \\
0 \\
36 \\
0 \\
0 \\
1 \\
0.25 \\
2.25 \\
1 \\
0\end{array}$ & $\begin{array}{c}0 \\
0 \\
1 \\
-1 \\
2 \\
-1 \\
-0.5 \\
0 \\
0 \\
0 \\
4 \\
-2.5 \\
0 \\
0 \\
-2 \\
-1 \\
3 . \\
-2\end{array}$ & $\begin{array}{l}0 \\
0 \\
1 \\
1 \\
4 \\
1 \\
0.25 \\
0 \\
0 \\
0 \\
16 \\
6.25 \\
0 \\
0 \\
4 \\
1 \\
9 \\
4\end{array}$ \\
\hline & \multicolumn{2}{|c|}{ Test: $\begin{array}{l}r_{B}=0.93 \\
P \geq 0.01\end{array}$} & \multicolumn{2}{|c|}{ Retest: $\begin{aligned} r_{8} & =0.95 \\
& P \geq 0.01\end{aligned}$} \\
\hline
\end{tabular}

Table IV: $\mathrm{I}_{\mathrm{g}}$ between SAS and L.M.T.A. 
changed for the purpose of translation. The divisions into subtests made it easy to omit items when the patients had been illiterate in Hebrew.

Nevertheless, it was considered desirable to use scores obtained on the L.M.T.A. by 18 out of the 20 patients in order to provide a control, and indicate validity of the SAS scores in Hebrew. The results on the two tests and retests (Table II and III) were ranked and the Spearman Rank Correlation Coefficient $r_{\mathrm{g}}$ was used to establish the correlation between the results on the two tests. A formula taking into account ties in ranking was used as described by Siegel ${ }^{5}$. The $r$ on the SAS and L.M.T.A. test results was 0.93 with a level of significance of $P=0.01$ (Table IV). On the retests the : obtained was 0.95 at a level of significance of $\mathrm{P}=0.01$ (Table IV). As the level of significance between the SAS and L.M.T.A. is high, it may be concluded that the two tests measure the same disorder. The L.M.T.A. was proved valid as a test of aphasia in Hebrew, by Bar-David', therefore it was assumed by

\begin{tabular}{c|c|c}
\cline { 2 - 3 } Case. & $\mathrm{d}_{1}$ & $\mathrm{~d}_{\mathrm{i}}^{2}$ \\
\hline 1 & -1.5 & 2.25 \\
2 & -0.5 & 0.25 \\
3 & -1.5 & 2.25 \\
4 & 4 & 16 \\
5 & -8 & 64 \\
6 & 0 & 0 \\
7 & 2 & 4 \\
8 & 0 & 0 \\
9 & 2.5 & 6.25 \\
10 & 1 & 1 \\
11 & -1 & 12.25 \\
12 & 3.5 & 2.25 \\
13 & -2.5 & 9 \\
14 & 3 & 9 \\
15 & -3 & 6.25 \\
16 & 2.5 & 2.25 \\
17 & 1.5 & 4 \\
18 & -2 & \\
19 & -2 & \\
20 & & \\
\hline & $\mathrm{r}_{\mathrm{P}}-0.88$ & \\
& $\mathrm{P}$ & \\
\hline
\end{tabular}

Table $V: \mathrm{r}_{\mathrm{a}}$ between SAS Test and H.L.Q. Test

((3) and (7) of Raw Scores)

the writer that the SAS was also valid. It should be noted that the "Tell a Story" item of the L.M.T.A. was omitted in the comparison of the two tests on the advice of Wepman ${ }^{9}$ who maintained that there was no comparable item in the SAS.

The patients used in this study came from ten different countries and spoke seven languages. Their ages ranged from 34 to 76 and their educational status from illiterate to University degree (Table I).

Tydskrif van die Suid-Afrikaanse Vereniging vir Spraak- en Gehoorheelkunde, Vol. 18, Desember 1971 


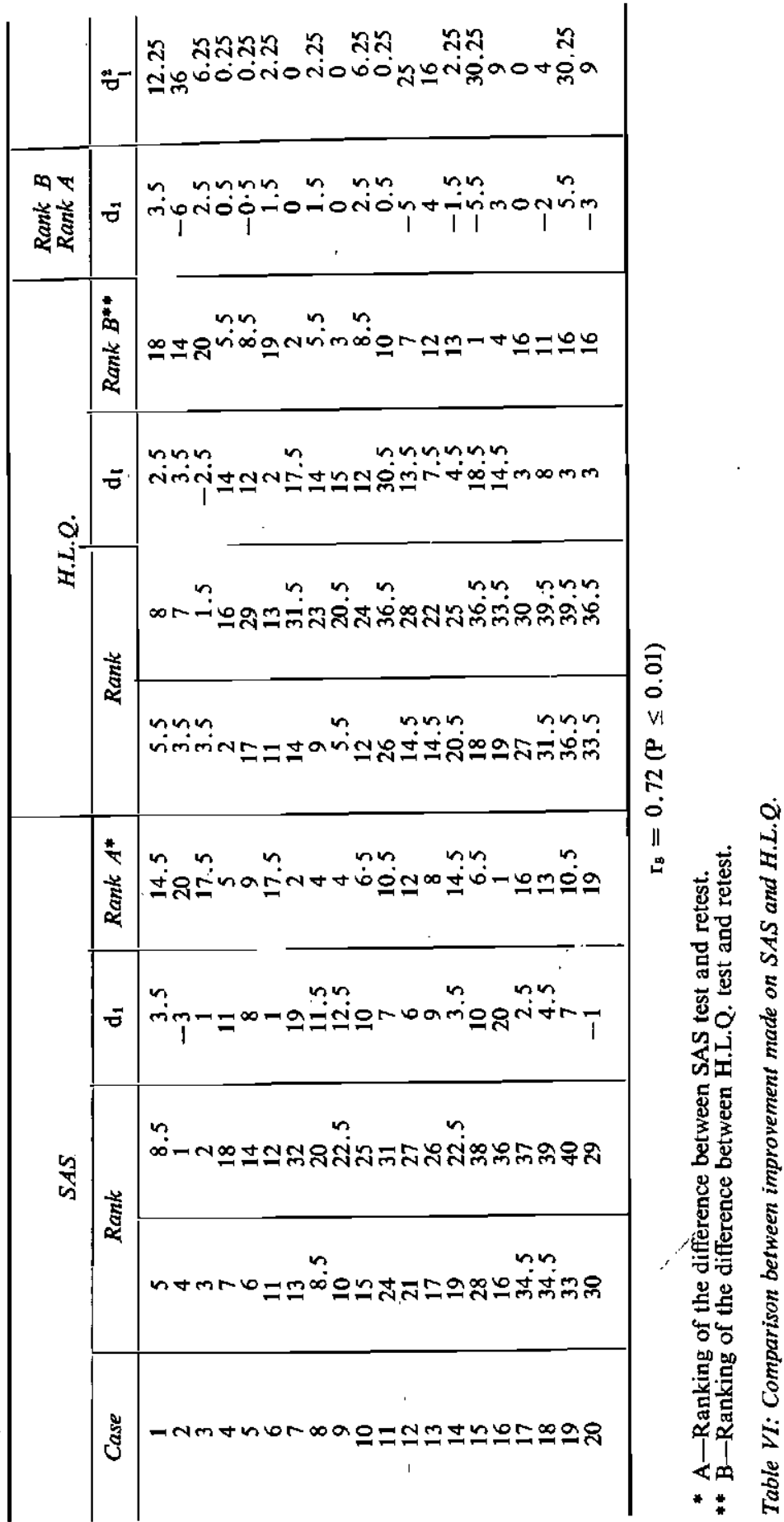

Journal of the South African Speech and Hearing Association, Vol, 18, December 197I 
As the purpose of the study carried out in Israel was to establish the influence of therapy in Hebrew on the home language of the bilingual or polyglot adult aphasic, a test in the patient's home language was also required. A Home Language Questionnaire was devised which consisted of 20 questions to test activities which the patient's family could observe. The patient was tested in his home language and the SAS before and after three month' treatment in Hebrew. The correlation between the Home Language Questionnaire and the SAS is shown in Table V. Where improvement was made on the SAS a similar improvement was indicated in the patient's home language (Table VI).

Thus it may be seen that the SAS proved to be a useful evaluating instrument in patients who had spoken a variety of languages prior to illness. This writer is of the opinion that the SAS would be suitable in other languages in many parts of the world.

\section{SUMMARY}

The Sklar Aphasia Scale was used to test 20 bilingual and polyglot aphasic patients in a project carried out in Haifa, Israel. The test was compared to the L.M.T.A. on 18 of the patients and proved to be valid. This writer believes that it is an easily translatable, adaptable scale which could be used for aphasics in other parts of the world where it is impractical to test the patient in his home language.

\section{OPSOMMING}

Die Sklar Afasieskaal is gebruik om 20 twee- en veeltalige afasiese gevalle te toets in Haifa, Israel.

Die toets is vergelyk teen die "Language Modality Test of Aphasia" wat op 18 van die proefpersone uitgevoer is en dit- het geblyk geldig te wees. Die skrywer glo dat hierdie 'n maklik vertaalbare en aanpasbare skaal is wat gebruik kan word vir Afasiegevalle in ander dele van die wêreld waar dit onprakties of onmoontlik is om die geval in sy huistaal te toets.

\section{ACKNOWLEDGEMENT}

This 'study was supported in part by Public Health Service Research Grant No. 06-12 1134-108-13 from the Bureau of Disease Prevention and Environment Control of the United States Government. The writer acknowledges with thanks the assistance given by Dahlia Bar-David in providing the L.M.T.A. scores for this study.

\section{REFERENCES:}

1. Bar-David, D. (1971): Adaptation of the Wepman-Jones Language Modalities Test for Aphasia into Hebrew. J. Communication Disorders, Vol. 4, No. 1.

2. Fredman, M. (1970): The Effect of Therapy Given in Another Language, on the Home Language of the Bilingual or Polyglot Adult Aphasic. M.A. Dissertation, University of the Witwatersrand, Johannesburg. 
3. McCloud, E. (1962): Comparison of Four Aphasia Tests Administered to 12 Persons. Chapter 4 of M.A. Thesis, University of California.

4. Schuell, H. (1965): Administrative Manual for the Minnesota Test for Differential Diagnosis of Aphasia. University of Minnesota Press, Minneapolis.

5. Siegel, S. (1956): Non-Parametric Statistics for the Behavioural Sciences. McGraw-Hill Book Co., Inc.

6. Sklar, M. (1963): Relations of Psychological and Language Test Scores and Autopsy Findings in Aphasia. J. Speech Hearing Research, Vol. 6, No. 1.

7. Sklar, M. (1966): Sklar Aphasia Manual. Western Psychological Services, California.

8. Wepman, J. M., Jones, L. V., Bock, R. D. and Van Pelt, D. (1961): Manual for Language Modality Test of Aphasia. University of Chicago, Education Industry Service.

9. Wepman, J. M. (1969): Personal correspondence. 